\title{
Dermatological diseases affecting fishes of the Tar-Pamlico Estuary, North Carolina
}

\author{
Edward J. Noga ${ }^{1}$, James F. Wright ${ }^{2}$, Jay F. Levine ${ }^{2}$, Michael J. Dykstra $^{2}$, \\ Jess H. Hawkins ${ }^{3}$ \\ ${ }^{1}$ Department of Companion Animal and Special Species Medicine, ${ }^{2}$ Department of Microbiology, Pathology, and Parasitology, \\ College of Veterinary Medicine, North Carolina State University, Raleigh, North Carolina 27606, USA \\ ${ }^{3}$ North Carolina Division of Marine Fisheries, PO Box 1507, Washington, North Carolina 27889, USA
}

\begin{abstract}
Over the last several years, various epidemic dermatological diseases have been observed in fishes of the Tar-Pamlico estuary. The most important is ulcerative mycosis, an infection associated with oomycete fungi that affects Atlantic menhaden Brevoortia tyrannus. In the present report we describe lesions resembling ulcerative mycosis in other estuarine species such as southern flounder Paralichthys lethostigma, hickory shad Alosa mediocris, striped bass Morone saxatilis, bluefish Pomatomus saltatrix, Atlantic croaker Micropogonias undulatus, weakfish Cynoscion regalis, spot Leiostomus xanthurus, silver perch Bairdiella chrysura, pinfish Lagodon rhomboides, and hogchoker Trinectes maculatus. Less prevalent dermatological diseases were also observed,including lymphocystis, bacterial dermatitis and myositis, Argulus dermatitis, Henneguya myositis, and various idiopathic dermatopathies. Only one tumor, a fibroma, was seen. The occurrence of many of these diseases is of concern to fisheries managers because of their potential impact upon estuarine fish populations. Many environmental problems (noxious algae blooms, increasing turbidity, anoxic/hypoxic events, loss of submerged aquatic vegetation, etc.) plague the Tar-Pamlico estuary. The relationship of the observed diseases to these environmental problems is presently unknown.
\end{abstract}

\section{INTRODUCTION}

Skin diseases appear to be an increasingly common problem in estuarine fishes of the Tar-Pamlico River, North Carolina, USA. The most common disease is ulcerative mycosis (UM), which was first recognized in Atlantic menhaden Brevoortia tyrannus from the TarPamlico estuary (Noga \& Dykstra 1986). Skin lesions were concurrently reported in other commercially important estuarine fishes in North Carolina (Noga \& Dykstra 1986). Recurrent outbreaks of ulcerative skin diseases in this and other estuarine systems have prompted increasing public concern about their impact on the productivity of the fishery (Rader et al. 1987 , Noga 1988)

Our previous studies with Atlantic menhaden have shown that ulcerative mycosis is associated with oomycete fungi. Aphanomyces has been most commonly cultured from UM lesions, but Saprolegnia has also been isolated (Dykstra et al. 1986, 1989). We have previously described the pathological characteristics of
UM in naturally affected menhaden (Noga et al. 1988) In this paper, we describe the dermatopathies affecting other fish species in the Tar-Pamlico estuary.

\section{MATERIALS AND METHODS}

Most fish were collected from pound nets set on the Tar-Pamlico River during July 1984 through July 1988 (Levine et al. 1990). Pound nets were usually sampled within $24 \mathrm{~h}$ of harvesting by commercial fishermen; thus, fish were not iatrogenically traumatized. Some fish were obtained from trawl samples of the Division of Marine Fisheries and local fishermen.

All fish were alive when captured and most were necropsied on site. Some were transported back to the laboratory on ice and immediately necropsied. Most lesions were preserved in either $10 \%$ neutral buffered formalin or Bouin's fluid, embedded in paraffin wax, and stained with hematoxylin and eosin (H\&E). Selected tissues were also stained with Gomori methenamine 
silver (GMS), periodic acid-Schiff, Giemsa, Brown and Brenn Gram's stain, a modified MacCallum-Goodpasture Gram's stain, Fite-Faraco acid fast or with Mallory's trichrome. Alternatively, some lesions were examined by preparing wet mounts of fresh material.

\section{RESULTS}

Forty-nine skin lesions from 11 species were examined (wet mounts from 4 fish and stained tissue sections from 45 fish). Fungal infections were identified in 21 fish (Table 1). Most cases were similar to ulcerative mycosis lesions described in Atlantic menhaden (Noga et al. 1988), being off-white to dark red, deep ulcers (Fig. 1A) that in some cases extended through the body wall. Chronic inflammation (Figs. 1C \& 2A) surrounded broad, aseptate hyphae (Figs. 1D \& 2B). Inflammation and hemorrhage also extended laterally under intact skin. Lymphocytes were common and eosinophilic granular cells were occasionally present. Muscle damage was often associated with the fungal

Table 1. Skin lesions observed on fishes in the Tar-Pamlico Estuary. Total numbers of each case. All fish were large juvenile to adult fish

\begin{tabular}{|c|c|c|c|c|c|c|c|c|}
\hline \multirow[b]{2}{*}{ Species } & \multirow[b]{2}{*}{$\begin{array}{l}\text { Fungal } \\
\text { myositis }^{\alpha}\end{array}$} & \multirow[b]{2}{*}{$\begin{array}{l}\text { Parasitic } \\
\text { dermatitis }\end{array}$} & \multirow[b]{2}{*}{$\begin{array}{c}\text { Bacterial } \\
\text { dermatitis }\end{array}$} & \multicolumn{2}{|c|}{ Diagnosis } & \multirow[b]{2}{*}{$\begin{array}{l}\text { Idiopathic } \\
\text { dermatitis }^{f}\end{array}$} & \multirow[b]{2}{*}{$\begin{array}{l}\text { Idiopathic } \\
\text { myositis }\end{array}$} & \multirow[b]{2}{*}{ Neoplasia } \\
\hline & & & & $\begin{array}{l}\text { Bacterial } \\
\text { myositis }\end{array}$ & $\begin{array}{l}\text { Lympho- } \\
\text { cystis }\end{array}$ & & & \\
\hline \multicolumn{9}{|l|}{ BOTHIDAE } \\
\hline $\begin{array}{l}\text { Southern flounder } \\
\text { Paralichthys lethostigma }\end{array}$ & 7 & & 1 & & & 3 & 1 & \\
\hline $\begin{array}{l}\text { CLUPEIDAE } \\
\text { Hickory shad } \\
\text { Alosa mediocris }\end{array}$ & $1^{b}$ & & & & & & & \\
\hline $\begin{array}{l}\text { Gizzard shad } \\
\text { Dorosoma cepedianum }\end{array}$ & & & & & & & 2 & $1^{\mathrm{g}}$ \\
\hline $\begin{array}{l}\text { White shad } \\
\text { Alosa sapidissima }\end{array}$ & & & & & & & 1 & \\
\hline $\begin{array}{l}\text { PERICHTHYDIAE } \\
\text { Striped bass } \\
\text { Morone saxatilis }\end{array}$ & $1^{b}$ & & & & & & & \\
\hline \multicolumn{9}{|l|}{ POMATOMIDAE } \\
\hline $\begin{array}{l}\text { Bluefish } \\
\text { Pomatomus saltatrix }\end{array}$ & 1 & & & & & & & \\
\hline \multicolumn{9}{|l|}{ SCIAENIDAE } \\
\hline $\begin{array}{l}\text { Atlantic croaker } \\
\text { Micropogonias undulatus }\end{array}$ & 2 & $1^{c}$ & & & 1 & 1 & & \\
\hline $\begin{array}{l}\text { Weakfish } \\
\text { Cynoscion regalis }\end{array}$ & 3 & $2^{d}$ & & $1^{\mathrm{e}}$ & & 6 & & \\
\hline $\begin{array}{l}\text { Spot } \\
\text { Leiostomus xanthunus }\end{array}$ & 2 & & $1^{\mathrm{e}}$ & $3^{e}$ & 1 & 1 & & \\
\hline $\begin{array}{l}\text { Silver perch } \\
\text { Bairdiella chrysuna }\end{array}$ & 2 & & 1 & & & & & \\
\hline $\begin{array}{l}\text { SOLEIDAE } \\
\text { Hogchoker } \\
\text { Trinectes maculatus }\end{array}$ & $1^{\mathrm{b}}$ & & & & & & & \\
\hline $\begin{array}{l}\text { SPARIDAE } \\
\text { Pinfish } \\
\text { Lagodon rhomboides }\end{array}$ & $1^{b}$ & & & & & & & \\
\hline $\begin{array}{l}\text { At least one individual of ea } \\
\text { diameter), aseptate hypha } \\
\text { inflammatory infiltrate } \\
\text { b Fish had deep skin ulcers } \\
\text { inflammatory response } \\
\text { "Henneguya sp. chronic der } \\
\text { d Argulus sp. mononuclear d } \\
\text { Long, thin, gram-variable } \\
\text { Most cases were small lesio } \\
\text { "Fibroma }\end{array}$ & $\begin{array}{l}\text { ch species } \\
\text { See text } \\
\text { ith } 7.5-12 \\
\text { hatitis } \\
\text { rmatitis } \\
\text { ds } \\
\text { is with lym }\end{array}$ & $\begin{array}{l}\text { Iad a UM-lik } \\
\text { for variatio } \\
\text { m aseptate } \\
\text { phocytic infi }\end{array}$ & $\begin{array}{l}\text { ne lesion (UN } \\
\text { ns in this } r \\
\text { nyphae, but } \\
\text { trates }\end{array}$ & $\begin{array}{l}\text { 1LL), define } \\
\text { esponse. } \\
\text { iistopatholo }\end{array}$ & $\begin{array}{l}\text { as a deep } \\
\text { fish exan } \\
\text { gy was not }\end{array}$ & $\begin{array}{l}\text { Ulcer with } \\
\text { ined histol } \\
\text { performed t }\end{array}$ & $\begin{array}{l}\text { road (at lea } \\
\text { gically hac } \\
\text { determine }\end{array}$ & $\begin{array}{l}\text { st } 7.5 \mu \mathrm{m} \text { in } \\
\text { a chronic } \\
\text { the type of }\end{array}$ \\
\hline
\end{tabular}




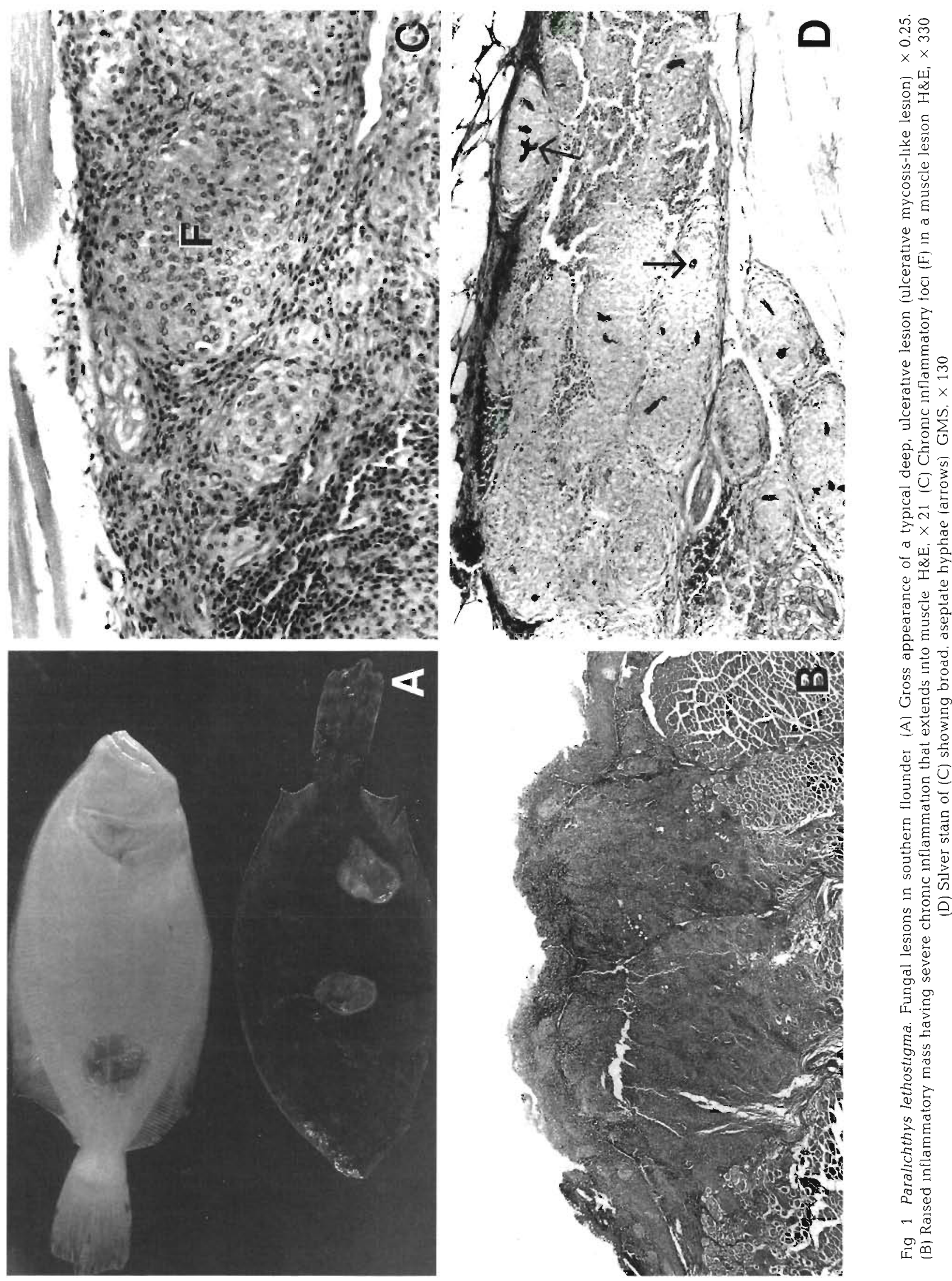



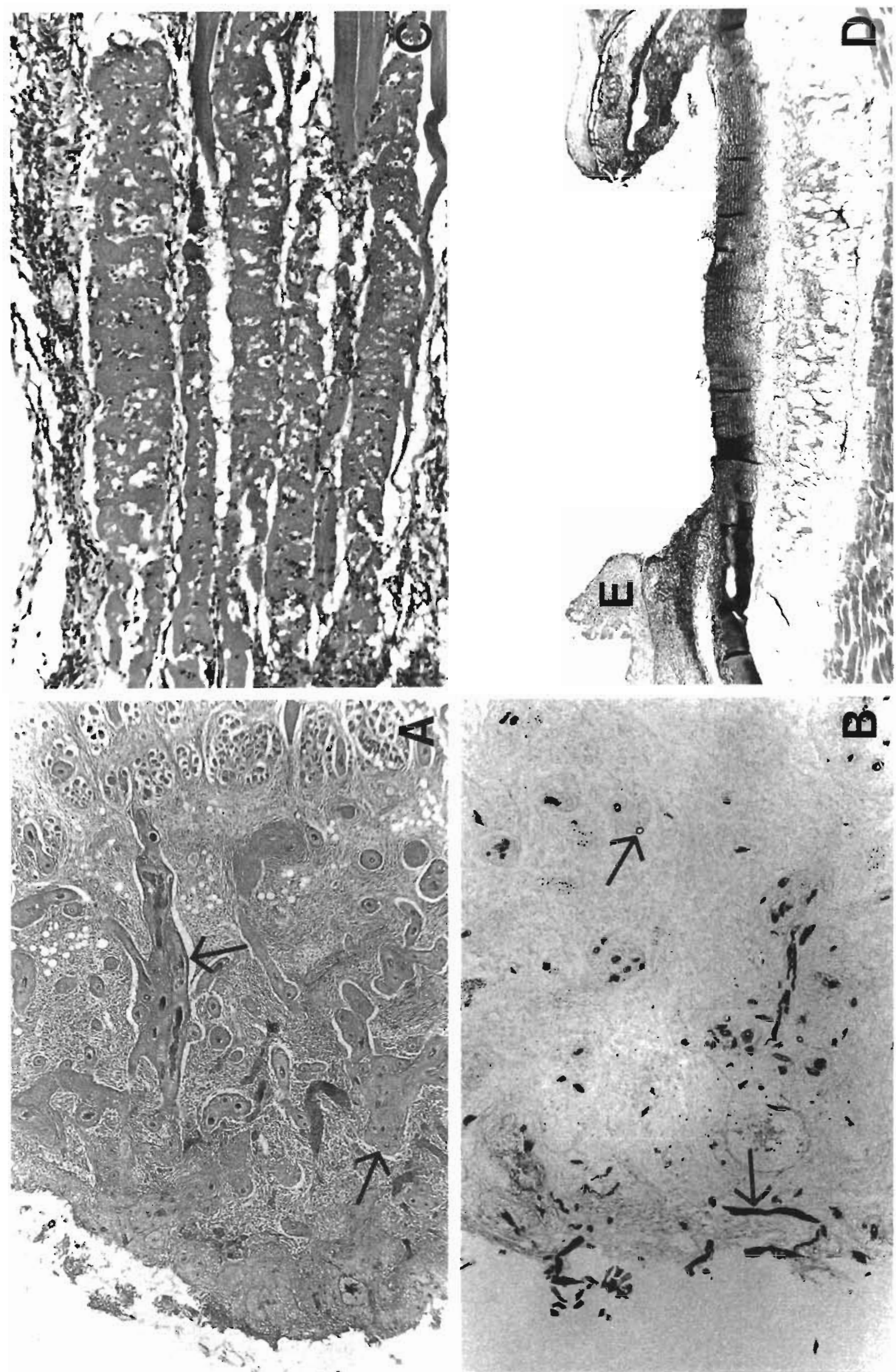

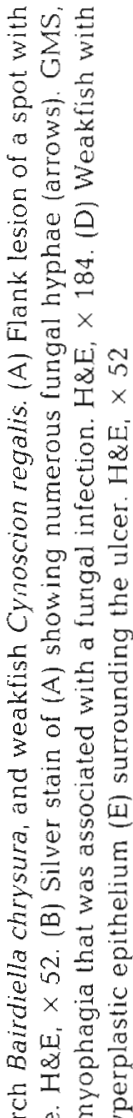

过主至

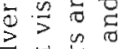

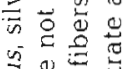

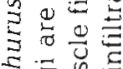

可蛇.

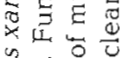

ริ

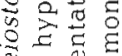

更宫号

$\stackrel{2}{2}$

일유

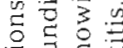

的总的

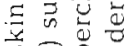

is

Q

远

๑ั

릉

$\because \frac{\pi}{2}$

ठํㅛㄹ

웅 荚

$\sum 0$

त :

을 
invasion and appeared as necrotic muscle fibers with loss of striations that were being phagocytized by macrophages (similar to that seen in Fig. 2C).

In addition to the deep ulcers described above, some fungal lesions in southern flounder were instead, flat, shallow ulcers or raised oval lesions up to $10 \mathrm{~mm}$ in diameter (Fig. 1B) having diffuse to organized inflammatory foci with macrophage-like cells. In some cases, the lesions were undergoing epithelial regeneration. Many other skin diseases were present in other sampled fish, including virus-, bacteria- and parasiteassociated lesions (Table 1, Fig. 2D). Some cases had no histologically detectable pathogens.

\section{DISCUSSION}

Most of the common fish species inhabiting the TarPamlico estuary are susceptible to deep fungal infections that are similar to those previously described in Atlantic menhaden (Levine et al. 1990), although the former fishes are much less frequently affected than menhaden (Levine et al. 1990). Affected species occupy virtually all ecological niches, from benthic carnivores (e.g. southern flounder Paralichthys lethostigma) to pelagic planktivores (e.g. hickory shad Alosa mediocris). All fish with these ulcerative mycosis-like lesions (UMLL) frequent low to moderate salinities. We have not seen UMLL in freshwater fishes of the Tar-Pamlico estuary, nor does it appear to affect species that are restricted to high salinities. For example, while the southern flounder is affected, the closely-related summer flounder Paralichthys dentatus, which is usually restricted to at least $10 \mathrm{ppt}$ salinity, has never been observed with UMLL in North Carolina (J. Hawkins unpubl.). Some estuarine species that frequent low to moderate salinities are not affected by UMLL, including longnose gar Lepisosteus osseus, bay anchovy Anchoa mitchilli, and American eel Anguilla rostrata (Levine et al. 1990, Hawkins unpubl.), although American eels commonly have ulcers due to Aeromonas salmonicida (Noga \& Berkhoff 1990). The reason for some species' resistance to UMLL is unknown.

The invading fungi in UMLL elicited 2 types of chronic inflammatory responses. In southern flounder, epithelioid granulomas were histologically similar to the mammalian epithelioid cell response. These cells had abundant ground-glass cytoplasm, vesicular nuclei, and indistinct cell borders (Fig. 1C). However, most fish responded to fungal invasion by producing inflammatory cells with more epithelial-like features (Fig. 2A) (Noga et al. 1989). Whether this represents a difference in host response or a difference in etiology awaits further study
The relatively low occurrence of UMLL in species other than menhaden (Levine et al. 1990) has hindered attempts to isolate the fungi. While definitive diagnosis of these lesions must await culture, Oomycetes are most likely the causative agents because broad aseptate hyphae are virtually pathognomonic for Oomycetes (Neish \& Hughes 1980). While Ichthyophonus also has broad aseptate hyphae, its other developmental (non-hyphal) stages are also present in lesions (Neish \& Hughes 1980).

Fungal skin ulcers have recently affected fishes in numerous estuarine systems along the Atlantic coast of the USA, including the Tar-Pamlico (Levine et al. 1990), St. Johns River, Florida (Grier \& Quintero 1987. Dykstra et al. 1989), Indian River, Florida (Grier \& Quintero 1987), and Chesapeake Bay, Maryland (Hargis 1985, Dykstra et al. 1989) estuaries. Weakfish Cynoscion regalis, redfish Sciaenops ocellatus, striped mullet Mugil cephalus, and white mullet Mugil curema have been reported with UMLL (Grier \& Quintero 1987).

Deep ulcerative fungal dermatopathies have also been reported in many freshwater and estuarine fishes throughout the world (Hatai et al. 1984, Boonyaratpalin 1985, Callinan et al. 1989). While the relationship of these other fungal diseases to UM is uncertain, the prevalence of such problems on a worldwide scale is of some concern.

Many other dermatopathies were seen in the sampled fishes, including parasitic, fungal, bacterial, and viral infections (Table 1). The relationship of these diseases to UMLL is uncertain, but they appear to be pathologically distinct from UMLL and probably represent different diseases. All of these diseases were uncommon compared to fungal infections (Levine et al. 1990)

Skin ulcers are indicative of polluted environments (Sindermann 1990), which suggests that poor water quality may be responsible for the preponderance of sick fish in the Tar-Pamlico estuary. Thus, future studies should focus on determining possible linkages between specific environmental conditions and specific diseases. While some have lumped these skin diseases into a single category such as 'ulcerative disease syndrome' (Hargis 1985) or 'red-sore disease' (Esch \& Hazen 1980), they differ in host range, infectious etiology, and seasonal distribution. Consequently, whether they share common environmental inducers remains to be determined.

Acknowledgements. We thank J. Reid and D. Moye for technical assistance. This work was supported by The University of North Carolina Water Resources Research Institute Grant \# 70054 and contract \# 5-35718 from the North Carolina Divison of Marine Fisheries. 


\section{LITERATURE CITED}

Boonyaratpalin, S. (1985). Fish disease outbreak in Burma. FAO Special Report. TCP/BUR/4402, $7 \mathrm{p}$

Callinan, R. B., Fraser, G. C., Vingona, J. L. (1989). Pathology of red spot disease in sea mullet, Mugil cephalus $\mathrm{L}$, from eastern Australia. J. Fish Dis. 12: $467-479$

Dykstra, M. J., Levine, J. F., Noga, E. J., Hawkins, J. H., Gerdes, P., Hargis, Jr., W. H., Grier, H. J., TeStrake, D. (1989). Ulcerative mycosis: a serious menhaden disease of the southeast coastal fisheries of the United States. J. Fish Dis. 12: 175-178

Dykstra, M. J., Noga, E. J., Levine, J. F., Hawkins, J. H., Moye, D. F. (1986). Characterization of the Aphanomyces species involved with ulcerative mycosis (UM) in menhaden. Mycologia 78: 664-672

Esch, G. W., Hazen, T. C. (1980). The ecology of Aeromonas hydrophila in Albemarle Sound, North Carolina. University of North Carolina Water Resources Research Institute Final Report \# 80-153, $116 \mathrm{p}$

Grier, H., Quintero, I. (1987). A microscopic study of ulcerated fish in Florida. Florida Bureau of Marine Research Report WM-164, St. Petersburg

Hargis, W. H. (1985). Quantitative effects of marine diseases on fish and shellfish populations. Trans. N. Am. Wildlife and Nat. Res. Conf. 50: 608-640

Hatai, K., Takahashi, S., Egusa, S. (1984). Studies on the pathogenic fungus of mycotic granulomatosis - IV Changes of blood constituents in both ayu, Plecoglossus

Responsible Subject Editor: T. Evelyn, Nanaimo, B. C., Canada altivelis experimentally inoculated and naturally infected with Aphanomyces piscicida. Fish Pathol. 19: 17-23

Levine, J. F., Hawkins, J. H., Dykstra, M. J., Noga, E. J., Moye, D. W., Cone, R. S. (1990). Species distribution of ulcerative lesions on finfish in the Tar-Pamlico estuary, North Carolina. Dis. aquat. Org. 8: $1-5$

Noga, E. J. (1988). Determining the relationship between water quality and infectious disease in fishery populations. Water Res. Bull. 24: 967-973

Noga, E. J., Berkhoff, H. A. (1990). Pathological and microbiological features of Aeromonas salmonicida infection in the American eel (Anguilla rostrata). Fish Pathol. 25: $127-132$

Noga, E. J., Dykstra, M. J. (1986). Oomycete fungi associated with ulcerative mycosis in menhaden, Brevoortia tyrannus (Latrobe). J. Fish Dis. 9: 47-53

Noga, E. J., Dykstra, M. J., Wright, J. F. (1989). Chronic inflammatory cells of fish possess epithelial cell characteristics. Vet. Path. 25: 429-437

Noga, E. J., Levine, J. F., Dykstra, M. J., Hawkins, J. H. (1988). Pathology of ulcerative mycosis in Atlantic menhaden Brevoortia tyrannus. Dis. aquat. Org. 4: 189-197

Rader, D. N., Loftin, L. F., McGee, B. A., Dorney, J. P., Clements, J. T. (1987). Surface water quality concerns in the TarPamlico River estuary. Water Quality Technical Report No. 87-04, N.C. Division of Environmental Management. 113 p.

Sindermann, C. J. (1990), Principal diseases of marine fish and shellfish. Vol. 1 Diseases of marine fish. Academic Press, New York

Manuscript first received: May 8, 1990

Revised version accepted: January 7, 1991 